The Journal of Animal \& Plant Sciences, 31(2): 2021, Page: 509-521

ISSN (print): 1018-7081; ISSN (online): 2309-8694

\title{
YIELD, ENERGY AND ECONOMIC ANALYSIS OF GREENHOUSE CUCUMBER (CUCUMIS SATIVUS L.) PRODUCTION UNDER DIFFERENT FARMING TREATMENTS
}

\author{
A. Zhanbota ${ }^{1}$, R. S. Noor ${ }^{2,3}$ and G. Y. Wang ${ }^{1,4^{*}}$ \\ ${ }^{1}$ College of Economics and Management, Northeast Agricultural University, Harbin 150030, China. \\ ${ }^{2}$ Department of Agriculture, Biological, Environment and Energy Engineering, College of Engineering, Northeast \\ Agricultural University, Harbin 150030, China. \\ ${ }^{3}$ Faculty of Agricultural Engineering \& Technology, PMAS-Arid Agriculture University, Rawalpindi 46000, Pakistan \\ ${ }^{4}$ School of Economics and Management, Chongqing University of Arts and Sciences 402160, China. \\ "Correspondence Author Email: awgy@cau.edu.cn
}

\begin{abstract}
Agrochemical based agriculture production is neither sustainable nor eco-friendly. A cost effective and sustainable organic farming is the need of time for better yield and quality. The efficient use of energy inputs improves productivity, profitability and economy. In this regard, we carried out this research for greenhouse hybrid cucumber (Kalam $\mathrm{F}_{1}$ ) production at Institute of Hydroponic Agriculture, Rawalpindi for the year 2017 to 2019 cropping season. The main objective was to evaluate the yield, energy and economic feasibility of greenhouse cucumber production under different farming treatments such as inorganic, organic and integrated fertilization application. The analysis was carried out based on energy use efficiency, energy productivity, benefits to cost ratio and amount of renewable and nonrenewable energies. The obtained results depicted that the total energy inputs for inorganic, organic and integrated greenhouse productions were 45856.3, 42945.3 and 54070.0 $\mathrm{MJ} \mathrm{ha}^{-1}$, respectively. Energy use efficiency was 4.19, 4.84 and 4.87 while the energy productivity was $1.25 \mathrm{~kg} \mathrm{MJ}^{-1}, 1.26 \mathrm{~kg} \mathrm{MJ}^{-1}$ and $1.40 \mathrm{~kg} \mathrm{MJ}^{-1}$ under inorganic, organic and integrated fertilizer treatments, respectively. The average percentages of direct, indirect, renewable and non-renewable energies were $11 \%$, $32.9 \%, 11.7 \%$ and $32.2 \%$ of the total energy, respectively. The net return of integrated farming treatment was highest $\left(43135.60 \$ \mathrm{ha}^{-1}\right)$ than organic (23555.33 $\left.\$ \mathrm{ha}^{-1}\right)$ and inorganic $\left(25127.93 \$ \mathrm{ha}^{-1}\right)$ farming treatments. Similarly, the benefit to cost ratio were 7.75, 6.03 and 6.57 , respectively from integrated to inorganic farming treatments. According to results, greenhouse cucumber production under integrated treatment showed high energy use efficiency, energy productivity, net return and benefit to cost ratio in comparison with organic and inorganic treatments which proved to be profitable practice for greenhouse cucumber production than organic and inorganic farming treatments.
\end{abstract}

Keywords: Greenhouse production, Cucumber, Organic farming, Energy analysis, Profitability.

\section{INTRODUCTION}

The imminent possibility of decreasing crop productivity arises due to continuous application of inorganic (synthetic) crop inputs, extreme use of irrigation and improper land management requires the adaptation and promotion of sustainable agriculture farming system. Organic agriculture utilizes all organic inputs during entire crop period, same as sustainable agriculture, as it has negligible negative affect on ecological health therefore, crucial to attain high agricultural production. Application of organic inputs promote soil fertility, biodiversity, public adaptation and entire shift toward organic agriculture belongs to sustainable agriculture (Kilcher, 2006; Noor et al., 2020a). A legitimate organic production system improves crop yield, alleviate crop returns and therefore, reduces food insecurity, mainly for small landholders.
Some studies considered economics sustainability (profit margin) as necessary for agricultural sustainability (Aslam et al., 2017). Additionally, the sustainable agriculture relates to three main characteristics such as maintaining better environmental quality, stability in productivity and social acceptability. Compared with conventional agriculture, the organic production system performs better in term of economics (Rigby and Caceres, 2001). Aslam and Hong, (2018a) stated that organic crop production system may not be considered the sustainable agriculture in all over the situations like in case of nitrate losses, there is a need to supply sufficient nutrient quantity through application of organic inputs. Aslam and Hong, (2018b) considered minimum application of inorganic fertilizer as a compulsory option for better crop productivity and sustainable agriculture. De Jager et al., (2001) interested in enhancing production, found it necessary to use inorganic input to some extent integrated with organic 
inputs in order to provide required nutrients for better soil health and crop yield.

The most intensive sector of world agriculture production is greenhouse agriculture system. It is intensive in sense of crop yield, annual production, energy consumption, investments and cost (Omid et al., 2011). Greenhouse farming enables the evaluations of small areas by providing high yield per unit area, besides it needs a regular labor use for agricultural activities. Similarly, agriculture under greenhouse increase water productivity, soil resource efficiency, and necessitate the profitable use of the water resources under restricted water availability due to global warming and increased water demand.

Greenhouse farming can be executed as single and double cropping. Single cropping is generally done in glass covered greenhouse and mono crop is obtained in a year. Double cropping is done in plastic cover greenhouse, the first crop is obtained in autumn, and the second crop is obtained in spring. A major part of the crops in the greenhouse are consumed in domestic markets and approximately $12 \%$ of these crops are exported.

In Pakistan, tomato, cucumber, pepper and other main consumable vegetables production are mainly carried under greenhouse with $79.9 \%$ of the total area under vegetable production. Tomato has the biggest share of production with $48 \%$ among the four crops while cucumber, pepper and others with $23.5 \%, 16.6 \%$ and $9.3 \%$ of total area under vegetable, respectively. Other vegetable kinds such as melon, bean and squash are grown in the greenhouses with the share of $2.6 \%$.

Energy use in a high yield agro-ecosystem such as greenhouse has become more intensive energy option due to the intensive use of energy inputs. The efficient use of energy resources increases crop production prevents frequent damage to natural resources and promote agricultural sustainability as an economical agricultural production system (Dalgaard et al., 2001). The greenhouse production is one of the most intensive crop production system and an energy-consuming branch in agriculture. In this system, the energy budget is important that is the numerical comparison of the relationship between inputs and outputs of a crop production system in terms of energy units (Canakci and Akinci, 2006).

Agricultural production and energy consumption are closely linked to each other. The efficient and effective use of energy is the key to enhanced sustainability of the agriculture production (Mohammadi and Omid, 2010). The units of energy use for agricultural production has been increased due to the use of pesticides, fertilizers, machinery, fuel, and electricity. The intensive energy use has produced environmental and human health problems; consequently, the efficient use of agricultural crop energy inputs has become an important factor for sustainable agriculture production (Yilmaz et al., 2005).

Energy productivity is an important index to determine the efficient use of energy inputs although higher energy productivity does not mean more economic possibility. However, energy input-output analysis describes the method to increase energy productivity by reducing energy inputs (Çebi et al., 2019). Increasing the energy efficiency of greenhouse production system is one of the most required energy studies in agriculture and the success in increasing energy efficiency in greenhouse farming determines the efficient use of energy resources. For this purpose, the input-output analysis in greenhouse is used to evaluate the environmental impacts and energy use efficiency of greenhouse organic and inorganic farming systems.

Several research studies were carried out on energy use efficiency and economic analysis of greenhouse cropping system to improve input-output energy analysis and evaluate the correlation between them, to name a few; Singh et al., 2003; Yuan and Peng, 2017; Noor et al., (2020b) Naresh et al., 2018; Yildizhan and Taki, 2018; Ilahi et al., 2019. Ekinci et al., (2020) investigated energy use for fruit production to improve energy efficiency. Aydin et al., (2019) investigated inputoutput energy relation to optimize energy sources for production of apricot. Mohammadi and Omid (2010) explored the energy budget in greenhouse cucumber cultivation in Iran. Ali et al., (2019) first time explored the energy ratios, energy forms, and GHG emission in the cultivation of cucumber under tunnel farming in Pakistan. Aslam et al., (2020) did the economic analysis of grafted cucumber production system in comparison with the real rooted hybrid-cucumber production system. However, in vegetable production system, researches conducted on energy use pattern are insufficient and demanded a detail exploration of utilization energy inputs and sources availability in greenhouse vegetable production. Thus, this research was carried out with specific objectives to (a) evaluate the energy input-output relationship for greenhouse cucumber production under organic, inorganic and integrated farming treatments (b) evaluate energy efficiency, energy productivity and their relationships for different farming treatments (c) evaluate the economics of different farming treatments in order to check suitability and acceptability.

\section{MATERIALS AND METHODS}

This experimental study was conducted for three consecutive seasons of 2017 to 2019 under controlled conditions (Temperature $28{ }^{\circ} \mathrm{C}$ and $90 \%$ humidity) with different fertilizer options in glass covered greenhouse at Floriculture Research Station, Institute of Hydroponic Agriculture located near Rawat, a $30 \mathrm{~km}$ from Rawalpindi on the way to Grand Trunk (GT) Road. The 
hybrid cucumber (Kalam $F_{1}$ ) was used as a material of the trails. The mentioned cultivars were mostly preferred because of better plant physiological growth, high fruit yield, and quality and highly resistive against soil borne diseases (Noor et al., 2019b; Aslam et al., 2020).

Scion and rootstock nursery were prepared in the first week of August during all three seasons in with peat moss and vermiculate ratio $1: 1(\mathrm{v} / \mathrm{v})$ as growing media to maintain better air-water composition. After 15 days, the grafting was performed depending upon the diameter of scion and rootstock and the grafts were shifted into disposable plastic pots filled with same growing media. Before the grafting process, plant material and tools were interacted with laminar flow of UV light to kill microbes. After 30-35 days, the grafted plants under uniform growing (temperature and humidity) conditions were transplanted into greenhouse having 20 $\mathrm{m} \times 50 \mathrm{~m}\left(1000 \mathrm{~m}^{2}\right)$ dimensions. The land was prepared conventionally for all treatments using M.B plough, Disc harrow, cultivator and soil leveler (Noor et al., 2019a). The soil characteristics were $\mathrm{pH} 7.3$, electrical conductivity (EC) $0.14 \mathrm{mS} \mathrm{cm}{ }^{-1}, \mathrm{NO}_{3} 15 \mathrm{mg} \mathrm{dm}^{3}, \mathrm{P} 4$ $\mathrm{mg} \cdot \mathrm{dm}^{3}$, K $31 \mathrm{mg} \mathrm{dm}$, Ca $28 \mathrm{mg} \mathrm{dm}{ }^{3}, \mathrm{Mg} 17 \mathrm{mg} \mathrm{dm}^{3}$, and total nitrogen $0.25 \%$. A recommended dose (25 tons) of well rotten farmyards manure was applied in relevant treatment (Organic, $\mathrm{T}_{2}$ ) combinations plots at the time of sowing while, the complete dose $\left(120 \mathrm{~kg} \mathrm{ha}^{-1}\right.$ each) phosphorus and potassium in the form of di-ammonium phosphate and murate were applied in $T_{1}$ inorganic treatment. The urea fertilizer (nitrogen) was fed in two equal doses at planting and flowering stages. The fertilizer as per treatments was thoroughly mixed in the soil with the help of weeding hoe. The trail was carried out according to completely randomized design (CRD) with three replications under each fertilizer treatment as shown in Table 1. Table 1 also presented the quantity of fertilizer applied under each treatment. The main objective of this study is the evaluation of energy inputoutput analysis of selected treatments, and to achieve the specific objective the major focus is on the energy use and economic analysis as described below.

Table 1. Fertilizer treatments and doses.

\begin{tabular}{cc}
\hline Fertilizer Treatments & Description \\
\hline Inorganic $\left(\mathrm{T}_{1}\right)$ & NPK (Recommended dose, $\left.150,120,120 \mathrm{~kg} \mathrm{ha}^{-1}\right)$ \\
Organic $\left(\mathrm{T}_{2}\right)$ & FYM (Recommended dose, 25 tones) \\
Integrated $\left(\mathrm{T}_{3}\right)$ & NPK $(50 \%)+$ FYM (Recommended dose, 25 tones) \\
\hline
\end{tabular}

Energy input-output analysis: The cucumber production systems involved several operations during entire crop period, and their energy requirements affect the total energy budget. For the calculation of energy equivalents for per hectare, the data comprised of the quantities of various energy inputs used per hectare was calculated for greenhouse cucumber production under three different farming treatments. Like, tractor use in farming operations, diesel fuel, chemicals, labor power, fertilizers, manure, irrigation water, electricity and seed and the production yields as outputs. All inputs were recorded per hectare basis. The amounts of inputs and outputs were calculated per hectare and multiplied by the energy equivalent coefficients. The calculations of experimental data were performed according to the averages of three years data. Energy equivalents for the inputs and outputs for greenhouse cucumber production were obtained from the previous studies as presented in Table 2. The energy equivalent coefficient showed the amount of energy (measured in $\mathrm{MJ}$ ) received from the use of 1 unit of input like human labor $\left(1.96 \mathrm{MJ} \mathrm{h}^{-1}\right)$, agricultural machinery $\left(62.7 \mathrm{MJ} \mathrm{h}^{-1}\right)$, nitrogen $(60.6 \mathrm{MJ}$ $\mathrm{kg}^{-1}$ ), phosphorus (11.15 $\mathrm{MJ} \mathrm{kg}^{-1}$ ), potassium (6.7 MJ $\left.\mathrm{kg}^{-1}\right)$, farmyard manure $\left(0.3 \mathrm{MJ} \mathrm{kg}^{-1}\right)$, cucumber nursery $\left(0.18 \mathrm{MJ} \mathrm{kg}^{-1}\right)$, irrigation water (1.02 MJ cubic meter $\left.{ }^{-1}\right)$, and diesel fuel $\left(50.23 \mathrm{MJ}\right.$ litre $\left.^{-1}\right)$ etc. The source of mechanical energy included direct use of tractors and consumed diesel oil. The mechanical energy was computed on the basis of total fuel consumption $\left(\mathrm{L} \mathrm{ha}^{-1}\right)$. Therefore, the energy consumed was calculated using conversion factors and was expresses in $\mathrm{MJ} \mathrm{ha}^{-1}$. Total input energy consumption was estimated by the addition of energy values from each input. Total output energy was calculated by multiplying total cucumber production with the energy equivalent of cucumber $\left(0.8 \mathrm{MJ} \mathrm{kg}^{-1}\right)$.

The expression used to determine energy use efficiency (energy ratio), energy productivity, specific energy and net energy are given as (Ozkan et al., 2011).

$$
\begin{aligned}
& \begin{array}{llllll}
E & u & e
\end{array} \quad=\begin{array}{lll}
E & O & \left(M n a^{-1}\right) \\
E & l 1 & \left(M n a^{-1}\right)
\end{array} \\
& E \quad p: \quad=\frac{Y \quad\left(k n a^{-1}\right)}{E \quad l 1 \quad\left(M n a^{-1}\right)} \\
& \text { Sk } \quad e \quad=\frac{E \quad l 1 \quad\left(M n a^{-1}\right)}{Y \quad\left(k n a^{-1}\right)}
\end{aligned}
$$

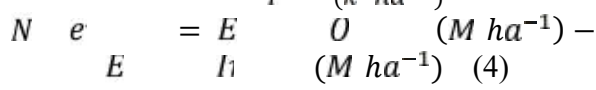


Table 2. List of energy equivalents of inputs and outputs in cucumber production.

\begin{tabular}{|c|c|c|}
\hline Energy sources & $\begin{array}{c}\text { Energy Equivalent } \\
\left(\text { MJ unit }{ }^{-1}\right)\end{array}$ & Literature cited \\
\hline \multicolumn{3}{|l|}{ Inputs } \\
\hline Human labor $(\mathrm{h})$ & 1.96 & (Ozkan et al., 2011). \\
\hline \multicolumn{3}{|l|}{ Fertilizer and pesticides $(\mathrm{kg})$} \\
\hline Nitrogen $(\mathrm{N})$ & 60.6 & Mengistu et al., 2018 \\
\hline Phosphorous $\left(\mathrm{P}_{2} \mathrm{O}_{5}\right)$ & 11.15 & Mengistu et al., 2018 \\
\hline Potassium $\left(\mathrm{K}_{2} \mathrm{O}\right)$ & 6.7 & Mengistu et al., 2018 \\
\hline Sulphur (S) & 1.12 & Mohammadi et al., 2008 \\
\hline Zinc $(\mathrm{Zn})$ & 8.4 & Mohammadi et al., 2008 \\
\hline Insecticides & 101.2 & Pellegrini and Fernández 2018; Houshyar et al., 2015 \\
\hline Fungicides & 181.9 & Pellegrini and Fernández 2018 \\
\hline Herbicides & 238.3 & Pellegrini and Fernández 2018 \\
\hline Farmyard manure $(\mathrm{kg})$ & 0.3 & Mohammadi et al., 2008 \\
\hline Seed $(\mathrm{kg})$ & 1.0 & Pellegrini and Fernández 2018 \\
\hline Diesel fuel (1) & 50.23 & Nabavi et al., 2016 \\
\hline Electricity (kWh) & 3.6 & Saad et al., 2016; Mohammadi et al., 2008 \\
\hline Tractor $(\mathrm{kg})$ & 93.61 & Khan et al., 2018 \\
\hline Electric motor $(\mathrm{kg})$ & 64.8 & Prajapat et al., 2018; Härtl et al., 2019 \\
\hline Agricultural machinery (kg) & 62.7 & Prajapat et al., 2018; Härtl et al., 2019 \\
\hline Irrigation water $\left(\mathrm{m}^{3}\right)$ & 1.02 & Ozkan et al., 2011 \\
\hline Plastic general (kg) & 90 & Ozkan et al., 2011 \\
\hline Wood $(\mathrm{kg})$ & 18.9 & Ekinci et al., 2020 \\
\hline Cucumber nursery & 0.18 & Calculated \\
\hline \multicolumn{3}{|l|}{ Outputs } \\
\hline Cucumber production $(\mathrm{kg})$ & 0.8 & Elisabeth et al., 2019; Pellegrini and Fernández 2018 \\
\hline Straw yield $(\mathrm{kg})$ & 7.5 & Pellegrini and Fernández 2018 \\
\hline \multicolumn{2}{|c|}{$\begin{array}{l}\text { Total energy inputs in cucumber production was } \\
\text { also categorized as direct and indirect or alternatively as } \\
\text { renewable and non-renewable energies (Bolandnazar et } \\
\text { al., 2019). The direct energy comes from human labor, } \\
\text { diesel fuel, and water for irrigation and electricity. The } \\
\text { indirect energy includes fertilizer, pesticides, seed, } \\
\text { machinery and farmyard manure. The non-renewable } \\
\text { energy comes from diesel fuel, machinery, pesticides, } \\
\text { fertilizers, and electricity. The renewable energy includes } \\
\text { seeds, water for irrigation, manure and human labor. } \\
\text { The construction cost and embodied energy } \\
\text { employed in the construction of the greenhouse was also }\end{array}$} & $\begin{array}{l}\text { calculated depending upon region. The effectively used } \\
\text { area of the greenhouse was } 20 \mathrm{~m} \mathrm{x} 50 \mathrm{~m}\left(1000 \mathrm{~m}^{2}\right) \text {. The } \\
\text { height of greenhouse was } 2.0 \mathrm{~m} \text { but, the center was } 5.5 \mathrm{~m} \\
\text { high and the volume was } 3750 \mathrm{~m}^{3} \text {. The surface of the } \\
\text { greenhouse is covered with a } 3 \mathrm{~mm} \text { thick glass and the } \\
\text { structural material was iron. The foundation was built } \\
\text { with } 0.25 \mathrm{~m} \text { thick concrete wall as boundary of floor area. } \\
\text { Table } 3 \text { showed the list of materials used in the } \\
\text { construction of the greenhouse (Tavares et al., 2019; Teh } \\
\text { et al., 2019). In this research, the average market prices } \\
\text { were used for the estimation of the construction cost for } \\
\text { the greenhouse. }\end{array}$ \\
\hline
\end{tabular}

Table 3. Energy embodied, and cost used for the construction of greenhouse $\left(20 \times 50 \mathrm{~m}^{2}\right)$.

\begin{tabular}{|c|c|c|c|c|c|}
\hline \multirow{2}{*}{ Item } & \multicolumn{3}{|c|}{ Energy embodied } & \multicolumn{2}{|c|}{ Total Cost } \\
\hline & Unit & $\left(\mathrm{MJ}\right.$ unit $\left.^{-1}\right)$ & Total energy (MJ) & Rate (\$) & $\operatorname{Cost}(\$)$ \\
\hline Metal (Iron), kg & 9025 & 27.73 & 250263.25 & 0.45 & 4061.25 \\
\hline Glass, $\mathrm{kg}\left(\mathrm{m}^{2}\right)$ & $10900(1445)$ & 12.7 & 138430 & 6.7 & 9681.5 \\
\hline Cement, kg (bag) & $1000(20)$ & 7.79 & 7790 & 2.93 & 58.6 \\
\hline Sand, kg & 41500 & 0.08 & 3320 & 2.5 & 103750 \\
\hline Screw, kg & 80 & 31.06 & 2484.8 & 1.72 & 137.6 \\
\hline Putty, kg & 1300 & 18.01 & 23413 & 0.83 & 1079 \\
\hline Paint, kg & 63 & 90.4 & 5695.2 & 1.72 & 108.36 \\
\hline Metal wire rods, $\mathrm{kg}$ & 92 & 12.5 & 1150 & 1.38 & 126.96 \\
\hline Labor cost & - & - & - & 1586 & 1586 \\
\hline Total & & & 432546.25 & & 120589 \\
\hline
\end{tabular}


The greenhouse was considered as 25 years life according to regional and material properties, the greenhouse embodied energy is 17,264.1 MJ per $1000 \mathrm{~m}^{2}$ cucumber production area for one year. The energy primarily used in different agricultural operations is listed in Table 4. Agricultural machinery and tractor use energy was estimated using following expression ( $\mathrm{Li}$ et al., 2019).

$$
M=\frac{G \times M \times 1}{T \times W}
$$

Where $M$ is machine energy $\left(\mathrm{MJ} \mathrm{ha}^{-1}\right), \mathrm{G}$ is the wight of machine $(\mathrm{kg}), M$ is the production energy (MJ $\mathrm{kg}^{-1}$ ), $\mathrm{T}$ is the total life (h) and $\mathrm{W}$ is the effective field capacity $\left(\mathrm{ha} \mathrm{h}^{-1}\right)$.

Diesel energy was measured by quantity of fuel consumed during crop production (Li et al., 2019).

$$
\mathrm{FC}=\mathrm{P}_{\mathrm{m}} \times \mathrm{R} \times \mathrm{SFC}
$$

Where FC is the fuel consumprion $\left(1 \mathrm{~h}^{-1}\right), \mathrm{P}_{\mathrm{m}}$ is the tractor horsepower $(\mathrm{kW}), \mathrm{R}$ is the loading ratio and $\mathrm{SFC}$ is specific fuel consumption taken as $0.31 \mathrm{kWh}^{-1}$.

Computerized data acuistion system consisted of a dynamometer $(50 \mathrm{kN})$, torque meter $(2000 \mathrm{Nm})$, data logger and a laptop was used to measure machines loading ratio. Electricity consumption for irrigation and spraying activities was counted by electric meter.

\begin{tabular}{|c|c|c|c|}
\hline \multirow[b]{2}{*}{ Operations (unit ha ${ }^{-1}$ ) } & \multicolumn{3}{|c|}{ Treatments } \\
\hline & Inorganic $\left(\mathbf{T}_{1}\right)$ & Organic $\left(T_{2}\right)$ & Integrated $\left(\mathrm{T}_{3}\right)$ \\
\hline \multicolumn{4}{|l|}{ Solarization } \\
\hline Man (h) & 42.6 & 42.6 & 42.6 \\
\hline Irrigation system (h) & 6.0 & 6.0 & 6.0 \\
\hline Irrigation water $\left(\mathrm{m}^{3}\right)$ & 600 & 600 & 600 \\
\hline Electricity $(\mathrm{kWh})$ & 7.5 & 7.5 & 7.5 \\
\hline Nylon $(\mathrm{kg})$ & 10.0 & 10.0 & 10.0 \\
\hline \multicolumn{4}{|l|}{ FYM application } \\
\hline $\operatorname{Man}(\mathrm{h})$ & 0.0 & 27.1 & 28.3 \\
\hline Tractor $(\mathrm{h})$ & 0.0 & 4.1 & 4.5 \\
\hline Diesel (1) & 0.0 & 9.3 & 10.2 \\
\hline FYM $(\mathrm{t})$ & 0.0 & 25.0 & 25.0 \\
\hline \multicolumn{4}{|l|}{ Land preparation } \\
\hline $\operatorname{Man}(\mathrm{h})$ & 49.0 & 49.0 & 49.0 \\
\hline Tractor (h) & 2.7 & 2.7 & 2.7 \\
\hline Diesel (1) & 6.5 & 6.5 & 6.5 \\
\hline \multicolumn{4}{|l|}{ Nursery transplanting } \\
\hline Man (h) & 25.5 & 24.5 & 25.2 \\
\hline Cucumber nursery & 50.0 & 50.0 & 50.0 \\
\hline \multicolumn{4}{|l|}{ Plant husbandry } \\
\hline Man (h) & 275.0 & 271.0 & 275.0 \\
\hline Strings $(\mathrm{kg})$ & 18.6 & 18.6 & 18.6 \\
\hline \multicolumn{4}{|l|}{ Plant protection } \\
\hline Man (h) & 38.3 & 0.0 & 37.6 \\
\hline Spray equipment & 38.3 & 0.0 & 37.6 \\
\hline Electricity (kWh) & 36.1 & 0.0 & 35.9 \\
\hline Insecticides & 15.5 & 0.0 & 14.4 \\
\hline Fungicides & 6.5 & 0.0 & 6.3 \\
\hline \multicolumn{4}{|l|}{ Fertilizer and irrigation } \\
\hline Man (h) & 16.0 & 15.0 & 16.0 \\
\hline Irrigation system (h) & 92.6 & 89.5 & 92.0 \\
\hline Irrigation water $\left(\mathrm{m}^{3}\right)$ & 3000.0 & 2700.0 & 2900.0 \\
\hline Electricity (kWh) & 115.7 & 113.0 & 115.0 \\
\hline $\mathrm{N}, \mathrm{P}, \mathrm{K}(\mathrm{kg})$ & $105.5,32.5,66.5$ & $0,0,0$ & $50,17,35$ \\
\hline \multicolumn{4}{|l|}{ Heating } \\
\hline Man (h) & 78.8 & 78.8 & 78.8 \\
\hline Heating equipment (h) & 78.8 & 78.8 & 78.8 \\
\hline Wood $(\mathrm{kg})$ & 748.0 & 748.0 & 748.0 \\
\hline Ventilation & & & \\
\hline
\end{tabular}

Table 4. Energy sources used in greenhouse cucumber production under different farming treatments. 


\begin{tabular}{lccc}
\hline Man (h) & 16.5 & 16.5 & 16.5 \\
Crop harvesting & 348.0 & 348.0 & 348.0 \\
Man (h) & & & \\
Transportation & 50.3 & 50.3 & 52.3 \\
Man (h) & 50.3 & 50.3 & 52.3 \\
Tractor (h) & 62.1 & 62.1 & 63.1 \\
Diesel (l) & & & 20.3 \\
Cleaning up & 20.3 & 20.3 & \\
Man (h) & & & 75678 \\
Output & 57333 & 54285 & 27070 \\
Cucumber yield (kg) & 19500 & 21900 & \\
Straw yield (kg) & & & \\
\hline
\end{tabular}

The tractor power or electric power was used to operate agricultural machinery for cucumber production, while transplanting, plant husbander, harvesting and cleaning up operation were carried out manually. Between July and August, the soil sterilization was performed by solarization process through covering soil surface with plastic sheet and setting up irrigation system. An electrical motor operated two-wheel sprayer with 200 litre spray tank capacity was used for spraying. Drip irrigation method was used in greenhouse including fertigation system. The locally iron sheet wood furnace was used for heating greenhouse, essentially during winter time when temperature drops below required temperature. Natural ventilation was done using manual windows. The cucmber fruite harvesting was performed manually.

Economic analysis: The economic analysis of cucumber production was done. The economic inputs of hybrid cucumber production mainly based on total fixed and variable costs (Benli, 2019; Mohamed et al., 2017). The variable costs included the costs of chemicals, fuel, human labor, seed, fertilizers, irrigation water, electricity, repair and maintenance and revolving interest. The fixed costs included general administration expenses, interest on land value, irrigation machine tools interest, irrigation machine tools depreciation value, the amortization of facility costs, the facility capital interest. Following formulae were used in the calculation of gross, absolute and relative profit indicators (Baran et al., 2017).

\begin{tabular}{|c|c|c|c|c|c|c|}
\hline$G$ & $r$ & $=Y$ & $(k$ & $\begin{array}{c}\left.h a^{-1}\right) \times Y \\
(7)\end{array}$ & $p$ & $(\$ / k)$ \\
\hline$G$ & $p$ & $=G$ & $r$ & $\begin{array}{l}-v \\
(8)\end{array}$ & $c_{1}$ & $(\$ / h a)$ \\
\hline$N$ & $p$ & $=G$ & $r$ & $\begin{array}{l}-p \\
(9)\end{array}$ & $c_{1}$ & $(\$ / h a)$ \\
\hline$R$ & & $p$ & $=\frac{G}{P}$ & $\begin{aligned} & r \\
&(10)\end{aligned}$ & & \\
\hline
\end{tabular}

\section{RESULTS AND DISCUSSION}

Analysis of energy use in greenhouse cucumber production: The results obtained for the operational energy requirements (inputs) for cucumber production under inorganic, organic and integrated treatment systems were calculated as 45856.3, 42945.3 and 54070.0 MJ $\mathrm{ha}^{-1}$, respectively (Table 5). The share of heating energy is highest in all treatments followed by irrigation and fertilization $\left(20.3 \%\right.$ in $\mathrm{T}_{1}$ and $17 \%$ in $\left.\mathrm{T}_{3}\right)$ and $\mathrm{FYM}$ application (19.6\% in $\left.\mathrm{T}_{2}\right)$. The heating energy 19232.4 MJ ha ${ }^{-1}$ was observed highest among all other input energy sources due to climatic and geographical conditions. According to weather reports, generally the air temperature start dropping from $28^{\circ} \mathrm{C}$ in first week of October and remain below in whole winter season. Therefore, it is obvious, a greenhouse needs proper heating system. The greenhouse heating was done using high energy wood material. In heated greenhouse, the energy input associated with heating fuel is significantly high. This experimental study was carried out in heated greenhouse so that high heating fuel consumed in the greenhouse. In order to improve the energy use, it is suggested that production should be done under unheated greenhouse or, if not possible, the heating system efficiency should be raised or substituted with cheap energy sources such as renewable (natural gas and/or solar) energy (Omid et al., 2011).

The maximum use of irrigation and fertilization energy was measured as $9313.9 \mathrm{MJ} \mathrm{ha}^{-1}$ in inorganic cucumber production (treatment $\mathrm{T}_{1}$ ) followed by integrated production $\left(9171.8 \mathrm{MJ} \mathrm{ha}^{-1}\right.$ in treatment $\mathrm{T}_{3}$ ) while the lowest energy (3366.0 $\mathrm{MJ} \mathrm{ha}^{-1}$ ) was measured in organic production in treatment $\mathrm{T}_{2}$ because no chemical fertilizers were applied. Some operations did not use energy consumption and their values were set to zero such as spraying energy in organic cucumber treatment $T_{2}$ and farmyard manure (FYM) application energy in inorganic treatment $T_{1}$. The energy share in FYM application 8404.1 $\mathrm{MJ} \mathrm{ha}^{-1}$ was kept similar both in organic and integrated production systems.

The total output energy is the sum of cucumber yield energy and straw yield energy. It was calculated with the measured quantities of cucumber yield and straw yield in Table 4. Total production of cucumber was $57333 \mathrm{~kg} \mathrm{ha}^{-1}, 54285 \mathrm{~kg} \mathrm{ha}^{-1}$, and $75678 \mathrm{~kg} \mathrm{ha}^{-1}$ for $\mathrm{T}_{1}$, $\mathrm{T}_{2}$ and $\mathrm{T}_{3}$ treatments, respectively (Table 4). The 
treatment $\mathrm{T}_{3}$ (integrated production system) showed highest $\left(263567.4 \mathrm{MJ} \mathrm{ha}^{-1}\right)$ total energy output followed by treatment $\mathrm{T}_{2}$ organic cucumber production $(207678.0$
MJ ha ${ }^{-1}$ ) and the lowest (192116.4 $\mathrm{MJ} \mathrm{ha}^{-1}$ ) was observed in inorganic production system, treatment $T_{1}$.

Table 5. Energy use and output in cucumber production under greenhouse.

\begin{tabular}{|c|c|c|c|c|c|c|}
\hline \multirow{3}{*}{ Operation } & \multicolumn{6}{|c|}{ Treatments } \\
\hline & \multicolumn{2}{|c|}{ Inorganic $\left(T_{1}\right)$} & \multicolumn{2}{|c|}{ Organic $\left(T_{2}\right)$} & \multicolumn{2}{|c|}{ Integrated $\left(\mathrm{T}_{\mathbf{3}}\right)$} \\
\hline & Energy $\left(\mathrm{MJ} \mathrm{ha}^{-1}\right)$ & $(\%)$ & Energy $\left(\mathrm{MJ} \mathrm{ha}^{-1}\right)$ & $(\%)$ & Energy $\left(\mathrm{MJ} \mathrm{ha}^{-1}\right)$ & $(\%)$ \\
\hline Solarization & 1998.7 & 4.4 & 1998.7 & 4.7 & 1998.7 & 3.7 \\
\hline FYM application & 0.0 & - & 8404.1 & 19.6 & 8404.1 & 15.5 \\
\hline Land preparation & 675.3 & 1.5 & 675.3 & 1.6 & 675.3 & 1.2 \\
\hline Transplanting & 59.0 & 0.1 & 57.0 & 0.1 & 58.4 & 0.1 \\
\hline Plant husbandry & 539.0 & 1.2 & 531.2 & 1.2 & 539.0 & 1.0 \\
\hline Spraying & 5357.4 & 11.7 & 0.0 & - & 5163.7 & 9.6 \\
\hline Irrigation and fertilization & 9313.9 & 20.3 & 3366.0 & 7.8 & 9171.8 & 17.0 \\
\hline Heating & 19232.4 & 41.9 & 19232.4 & 44.8 & 19232.4 & 35.7 \\
\hline Ventilation & 32.3 & 0.1 & 32.3 & 0.1 & 32.3 & 0.1 \\
\hline Harvesting & 682.1 & 1.5 & 682.1 & 1.6 & 682.1 & 1.3 \\
\hline Transportation & 7926.5 & 17.3 & 7926.5 & 18.5 & 8070.5 & 14.9 \\
\hline Cleaning up & 41.7 & 0.1 & 39.8 & 0.1 & 41.7 & 0.1 \\
\hline Total energy input & 45856.3 & 100.0 & 42945.3 & 100.0 & 54070.0 & 100.0 \\
\hline Cucumber yield & 45866.4 & - & 43428.0 & - & 60542.4 & - \\
\hline Straw yield & 146250.0 & - & 164250.0 & - & 203025.0 & - \\
\hline Total energy outputs & 192116.4 & - & 207678.0 & - & 263567.4 & - \\
\hline
\end{tabular}

Equations 1 to 4 were used to calculate the energy use efficiency, energy productivity, specific energy and net energy of cucumber productions for all treatments. Energy use efficiency were calculated as 4.19, 4.84 and 4.87 in inorganic, organic and integrated production systems, respectively (Fig.1). The organic and inorganic treatments showed significantly similar energy use efficiency. This depicted the efficient use of energy input sources in greenhouse cucumber production. The score of energy efficiency is better as compared to previous research studies such as 0.69 (Omid et al., 2011), and 0.64 (Mohammadi and Omid, 2010). Others calculated energy use efficiency for greenhouse cucumber productions as 0.27 (Sami and Rehani, 2015) in Iran, 0.33 (Yousefi, et al., 2012) in Iran, 0.31 (Canakci and Akinci, 2006) in Turkey, 0.38 (Kuswardhani et al., 2013) in Indonesia, 0.56 (Taki et al., 2012) in Iran, and 0.76 Ozkan et al., 2011) in Turkey. Energy use efficiency is the ratio between total energy output to total energy input and it shows that the output energy was 4.19 MJ, 4.84 MJ, and 4.87 $\mathrm{MJ}$ for the use of $1 \mathrm{MJ}$ energy as an input for treatments $T_{1}, T_{2}$ and $T_{3}$, respectively. In this study the residue of crops collected as straw yield is also incorporated to calculate the total output energy to make the system more efficient and stable.

The energy productivity of cucumber crops under treatment $T_{1}, T_{2}$ and $T_{3}$ were calculated as 1.25, 126 and $1.40 \mathrm{~kg} \mathrm{MJ}^{-1}$ of three cucumber production systems, respectively. This indicated that $1.25,1.26$ - and 1.40-unit outputs were received per unit of input energy consumed. Energy productivity is more as compared to $0.80 \mathrm{Kg} \mathrm{MJ}^{-1}$ (Mohammadi and Omid, 2010). The specific energy is an index that indicates how much energy is utilized to produce a single unit of product. The specific energy of cucumber crop was calculated as 0.80 $\mathrm{MJ} \mathrm{kg}{ }^{-1}, 0.79 \mathrm{MJ} \mathrm{kg}^{-1}$ and $0.71 \mathrm{MJ} \mathrm{kg}^{-1}$ for inorganic, organic and integrated greenhouse production systems. This showed that one $\mathrm{kg}$ of cucumber production required such amount of energy, respectively under $T_{1}, T_{2}$ and $T_{3}$ treatments. The specific energy was less than 1 for all treatments which is less as compared with $1.72 \mathrm{MJ} \mathrm{kg}^{-1}$ (Abdi et al., 2012). Net energy means the difference between energy used and energy output. The calculated net energy of greenhouse cucumber production was maximum (209497.44 $\mathrm{MJ} \mathrm{ha}^{-1}$ ) under integrated fertilizer option $\left(\mathrm{T}_{3}\right)$ followed by $\mathrm{T}_{2}\left(164732.72 \mathrm{MJ} \mathrm{ha}^{-1}\right)$ organic fertilizer system while, the lowest positive net energy (146260.08 MJ ha ${ }^{-1}$ ) was calculated for inorganic fertilizer treatment. The net energy values were positive for all treatments that showed no energy lost during cucumber production in greenhouse systems. The energy budgeting (energy use efficiency $>1$; energy productivity $>1$; specific energy $<1$; and net energy $>0$ ) implies that the cucumber cultivation under greenhouse system is feasible but higher cucumber yield under integrated fertilizer treatment $T_{3}$ make the greenhouse cucumber production more feasible and adoptive. 


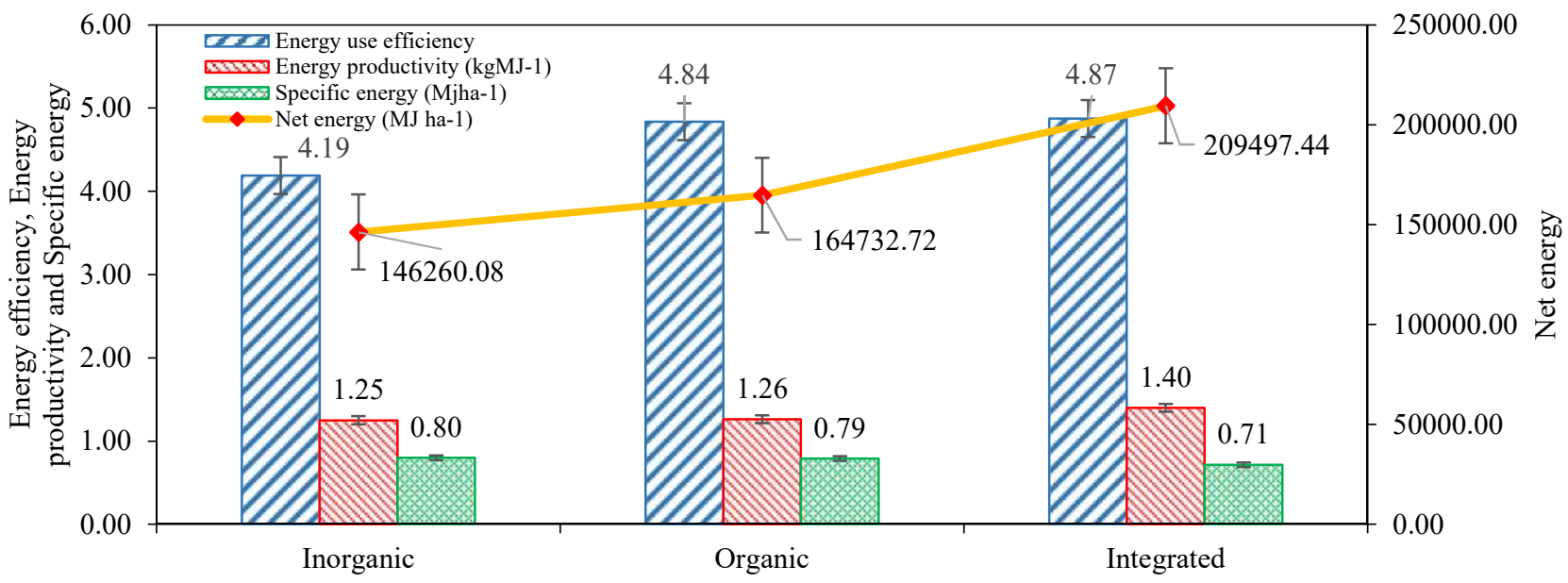

Figure 1. Energy budgeting parameters for cucumber production under different fertilizer treatments.

Energy utilization in different sources of cucumber production: The total energy utilized from multiple energy sources were 93631.8 $\mathrm{MJ} \mathrm{ha}^{-1}, 84935.6 \mathrm{MJ} \mathrm{ha}^{-1}$ and 89226.9 $\mathrm{MJ} \mathrm{ha}^{-1}$ to produce cucumber under integrated, organic and inorganic production systems, respectively (Table 6). Among the different utilized energy sources, the greenhouse structure, agricultural machinery, tractor and wood energies were calculated highest with a mean value of 36169.4, 17892.6 and 14137.2 MJ $\mathrm{ha}^{-1}$, respectively and accounts approximately $75 \%$ of the total energy utilized from different energy sources. These high-energy input sources can affect the ratio of other input energy sources. In this research study, the greenhouse was covered with glass material, which also contributed as high-energy value. This glass material significantly increased the total structural energy of greenhouses. The results suggested the needs to consider the use of glass greenhouse farming for better energy efficiency.

The fertilizer energy in organic production was zero while, in integrated cucumber production system the fertilizer energy was half of the energy used under inorganic cucumber production system. On the other hand, both organic and integrated production systems received equal FYM energy but not in inorganic cucumber farming. The spray material energy was in range 2603.3 to $2751.0 \mathrm{MJha}^{-1}$ in all treatments and were almost similar because of using same amount of chemical spray.

The results are not associated with high cucumber productions and a greater number of transportation cycles. In all production systems, the machinery energy ranges from 16273.17 to $18918.9 \mathrm{MJ}$ $\mathrm{ha}^{-1}$. Each number of spraying and transportation increased machinery energy by $5.6 \%$. The electric energy utilization was found fractionally varied because of using same operations. The highest values $3.6 \%$ was calculated under inorganic cucumber production due to highpowered electric pump used for spraying and irrigation operations. Plastic and plant energy were same in three production systems while the irrigation energy was less in organic production than other two production systems. Under such production systems, the efficient use of input energy sources could help to attain high production and productivity and resulted in an economical practice and higher profitable greenhouse production (Mohammadi and Omid, 2010).

The other variables: The cucumber yields (57,333 and 19,500 and $\left.54,285 \mathrm{~kg} \mathrm{ha}^{-1}\right)$ and straw yields $(21,900$ and 75,678 and $27,070 \mathrm{~kg} \mathrm{ha}^{-1}$ ) of cucumber was calculated from inorganic, organic and integrated greenhouse production systems, respectively. The energy ratio was calculated maximum in integrated cucumber production followed by organic production and inorganic production system. The specific energy requirement was highest in inorganic production $0.8 \mathrm{MJ} \mathrm{kg}^{-1}$ followed by organic production (0.79 $\left.\mathrm{MJ} \mathrm{kg}^{-1}\right)$ and integrated cucumber production $\left(0.71 \mathrm{MJ} \mathrm{kg}^{-1}\right)$. The energy productivity in greenhouse cucumber production ranges from 1.25 to $1.40 \mathrm{MJ} \mathrm{kg}^{-1}$. The calculated output energy sources were different to other studies. Many other earlier researches showed the energy ratios of greenhouse vegetable production were lower ranges from 0.19 to 0.32 that are due to high greenhouse structural, agricultural machinery and heating energies.

Energy inputs as direct, indirect, renewable and non-renewable forms are given in Table 7 . These are different forms of energy in cucumber production under three treatments. The results showed that shares of nonrenewable energy are higher than all other forms in all treatments followed by indirect energy and direct energy. Consistently the share of non-renewable energy was maximum $(89.07 \%)$ in greenhouse cucumber in Iran (Mohammadi and Omid, 2010). The share of direct and indirect energy in the integrated cucumber production was calculated as 11.7 and $34.6 \%$ of total energy input, respectively while it was 12.6 and $28.1 \%$ in organic 
treatment of cucumber (Table 7). The percentages of renewable energy $(6.2,15.0$ and 13.9) and non-renewable energy (52.2, 41.2 and 46.6) for three greenhouse production systems respectively indicated that inorganic treatment use major share of non-renewable energy. The share of renewable energy is high in organic treatment than integrated and inorganic treatments because of FYM application energy. It is also required to increase the share of renewable energy in green production for the protection of environment. Renewable energy sources are clean and green energy sources and should be adopted and encouraged for greenhouse cucumber production for better environmental impact and energy conservation. On the other hand, non-renewable sources are limited and are depleting with time. The results showed that the greenhouse production mainly depends on machinery use and less human labor.

Table 6. Energy used from different sources in greenhouse cucumber production.

\begin{tabular}{|c|c|c|c|c|c|c|}
\hline \multirow{2}{*}{ Sources } & \multicolumn{2}{|c|}{ Inorganic $\left(\mathrm{T}_{1}\right)$} & \multicolumn{2}{|c|}{ Organic $\left(\mathbf{T}_{2}\right)$} & \multicolumn{2}{|c|}{ Integrated $\left(\mathrm{T}_{3}\right)$} \\
\hline & $\left(\mathrm{MJ} \mathrm{ha}^{-1}\right)$ & $(\%)$ & $\left(\mathrm{MJ} \mathrm{ha}^{-1}\right)$ & $(\%)$ & $\left(\mathrm{MJ} \mathrm{ha}^{-1}\right)$ & $(\%)$ \\
\hline Human & 1884.1 & 2.1 & 1848.5 & 2.2 & 1939.6 & 2.1 \\
\hline Plant & 9.0 & 0.01 & 9.0 & 0.01 & 9.0 & 0.01 \\
\hline Machinery and tractor & 18485.72 & 20.7 & 16273.17 & 19.2 & 18918.9 & 20.2 \\
\hline Plastic & 900.0 & 1.0 & 900.0 & 1.1 & 900.0 & 1.1 \\
\hline Diesel & 3445.8 & 3.9 & 3958.1 & 4.7 & 4008.1 & 4.3 \\
\hline Electric & 573.5 & 0.6 & 570.2 & 0.7 & 570.2 & 0.6 \\
\hline Irrigation water & 3672.0 & 4.1 & 3366.0 & 4.0 & 3570.0 & 3.8 \\
\hline Fertilizers & 7201.2 & 8.1 & 0.0 & - & 3454.1 & 3.7 \\
\hline FYM & 0.0 & - & 7500.0 & 8.8 & 7500.0 & 8.0 \\
\hline Spray chemical & 2751.0 & 3.1 & 0.0 & - & 2603.3 & 2.8 \\
\hline Wood & 14137.2 & 15.8 & 14137.2 & 16.6 & 14137.2 & 15.1 \\
\hline Greenhouse structure & 36169.4 & 40.5 & 36169.4 & 42.6 & 36169.4 & 38.6 \\
\hline Total & 89226.9 & 100 & 84935.6 & 100 & 93631.8 & 100 \\
\hline
\end{tabular}

Table 7. The physical inputs, outputs and their energy equivalents for cucumber production under different fertilizer options.

\begin{tabular}{|c|c|c|c|c|c|c|}
\hline \multirow{2}{*}{ Energy type } & \multicolumn{2}{|c|}{ Inorganic $\left(T_{1}\right)$} & \multicolumn{2}{|c|}{ Organic $\left(T_{2}\right)$} & \multicolumn{2}{|c|}{ Integrated $\left(\mathrm{T}_{3}\right)$} \\
\hline & $\mathrm{MJ} \mathrm{ha}^{-1}$ & $(\%)^{*}$ & $\mathrm{MJ} \mathrm{ha}^{-1}$ & $(\%)^{*}$ & $\mathrm{MJ} \mathrm{ha}^{-1}$ & $(\%)^{*}$ \\
\hline Direct energy $^{\mathrm{a}}$ & 10475.4 & 11.7 & 10642.8 & 12.6 & 10988.0 & 11.7 \\
\hline Indirect energy ${ }^{\mathrm{b}}$ & 28446.9 & 31.9 & 23782.2 & 28.1 & 32485.2 & 34.6 \\
\hline Renewable energy ${ }^{c}$ & 5565.1 & 6.2 & 12723.5 & 15.0 & 13018.6 & 13.9 \\
\hline Non-renewable energy ${ }^{d}$ & 46594.4 & 52.2 & 34938.7 & 41.2 & 43691.7 & 46.6 \\
\hline
\end{tabular}

${ }^{*}$ Indicates percentage of total input energy

${ }^{a}$ Direct energy includes human, diesel, plastic, electricity and irrigation water energies.

${ }^{\mathrm{b}}$ Indirect energy includes fertilizer, spray, FYM, plant and machinery \& tractor energies.

${ }^{\mathrm{c}}$ Renewable energy includes human, FYM, plant and irrigation water energies.

${ }^{\mathrm{d}}$ Non-renewable energy includes diesel, spray, fertilizer, machinery and electric energies.

Economic analysis: The total cost of production per hectare was calculated as 4513.58 \$, 4682.18 \$ and $5056.90 \$$ for the inorganic, organic and integrated greenhouse cucumber production systems, respectively (Table 8). The ratio of total variable cost to total fixed cost were measured as 1.0, 1.1 and 1.3 in three different treatment systems, respectively. It indicated more than half of the production cost was constituted by variable cost in greenhouse cucumber farming. The results are in line with previous studies who reported that the variable costs are higher than fixed costs in greenhouse cropping system (Yelmen et al., 2019; Pellegrini and Fernández 2018; Sami and Rehani, 2015; Taki et al. 2012).
Moreover, the high construction cost of greenhouse was the main reason for high production cost while higher crop productivity is the main factor for adaptation of greenhouse production system.

The gross return (output) value of the production was calculated by multiplying the cucumber yield and straw yield by their respective prices. All the prices were collected in local currency in Pakistan rupees (PKR as Rs) and then converted into international currency American dollar (USD as \$) by multiplying with conversion factor as $1 \mathrm{USD}=125 \mathrm{PKR}$. The conversion factor is the average of currency exchange rate during fiscal year 2017 to 2019 . The gross output values were 
found 29641.5, 28237.5 and 39192.5 $\$ \mathrm{ha}^{-1}$ for the inorganic organic and integrated greenhouse cucumber production systems, respectively. The gross profit value was calculated by subtracting total variable cost from gross output value and it was found as 27360.92,
25788.33 and $36368.60 \$ \mathrm{ha}^{-1}$ for $\mathrm{T}_{1}, \mathrm{~T}_{2}$ and $\mathrm{T}_{3}$ treatments, respectively. It is mandatory to obtain a net income in an enterprise; gross profit value must be higher than the fixed costs. According to the research results, the gross output values were found higher than fixed costs.

Table 8. Production cost items and economic analysis of greenhouse cucumber production.

\begin{tabular}{lccc}
\hline Cost items $\left(\$\right.$ ha $\left.^{-1}\right)$ & Inorganic $\left(\mathbf{T}_{\mathbf{1}}\right)$ & Organic $\left(\mathbf{T}_{\mathbf{2}}\right)$ & Integrated $\left(\mathbf{T}_{\mathbf{3}}\right)$ \\
\hline Human labor & 1200.375 & 1178.875 & 1237 \\
Diesel \& lubrication & 82.50 & 78.30 & 82.00 \\
Nursery & 215 & 200 & 205 \\
Fertilizer and Pesticides & 400 & 0 & 300 \\
Water and Electricity & 247.8 & 232.1 & 240 \\
Farmyard manure & 0 & 625 & 625 \\
Wood & 49.9 & 49.9 & 49.9 \\
Repair maintenance costs & 85 & 85 & 85 \\
Total variable costs $\left(\$ \mathrm{ha}^{-1}\right)$ & $\mathbf{2 2 8 0 . 5 8}$ & $\mathbf{2 4 4 9 . 1 8}$ & $\mathbf{2 8 2 3 . 9 0}$ \\
Greenhouse depreciation & 351 & 351 & 351 \\
Machinery depreciation & 76 & 76 & 76 \\
Interest on greenhouse & 510 & 510 & 510 \\
Interest on machinery & 204 & 204 & 204 \\
Land rent & 833 & 833 & 833 \\
Machinery housing & 69 & 69 & 69 \\
General overhead costs & 190 & 190 & 190 \\
Total fixed costs $\left(\$ \mathrm{ha}^{-1}\right)$ & $\mathbf{2 2 3 3}$ & $\mathbf{2 2 3 3}$ & $\mathbf{2 2 3 3}$ \\
Total production costs $\left(\$ \mathrm{ha}^{-1}\right)$ & $\mathbf{4 5 1 3 . 5 8}$ & $\mathbf{4 6 8 2 . 1 8}$ & $\mathbf{5 0 5 6 . 9 0}$ \\
Total return $\left(\$ \mathrm{ha}^{-1}\right)$ & $\mathbf{2 9 6 4 1 . 5 0}$ & $\mathbf{2 8 2 3 7 . 5 0}$ & $\mathbf{3 9 1 9 2 . 5 0}$ \\
Net return $\left(\$ \mathrm{ha}^{-1}\right)$ & $\mathbf{2 5 1 2 7 . 9 3}$ & $\mathbf{2 3 5 5 5 . 3 3}$ & $\mathbf{3 4 1 3 5 . 6 0}$ \\
Benefit $/$ Cost ratio $(\mathbf{B C R})$ & $\mathbf{6 . 5 7}$ & & $\mathbf{6 . 0 3}$ \\
\hline
\end{tabular}

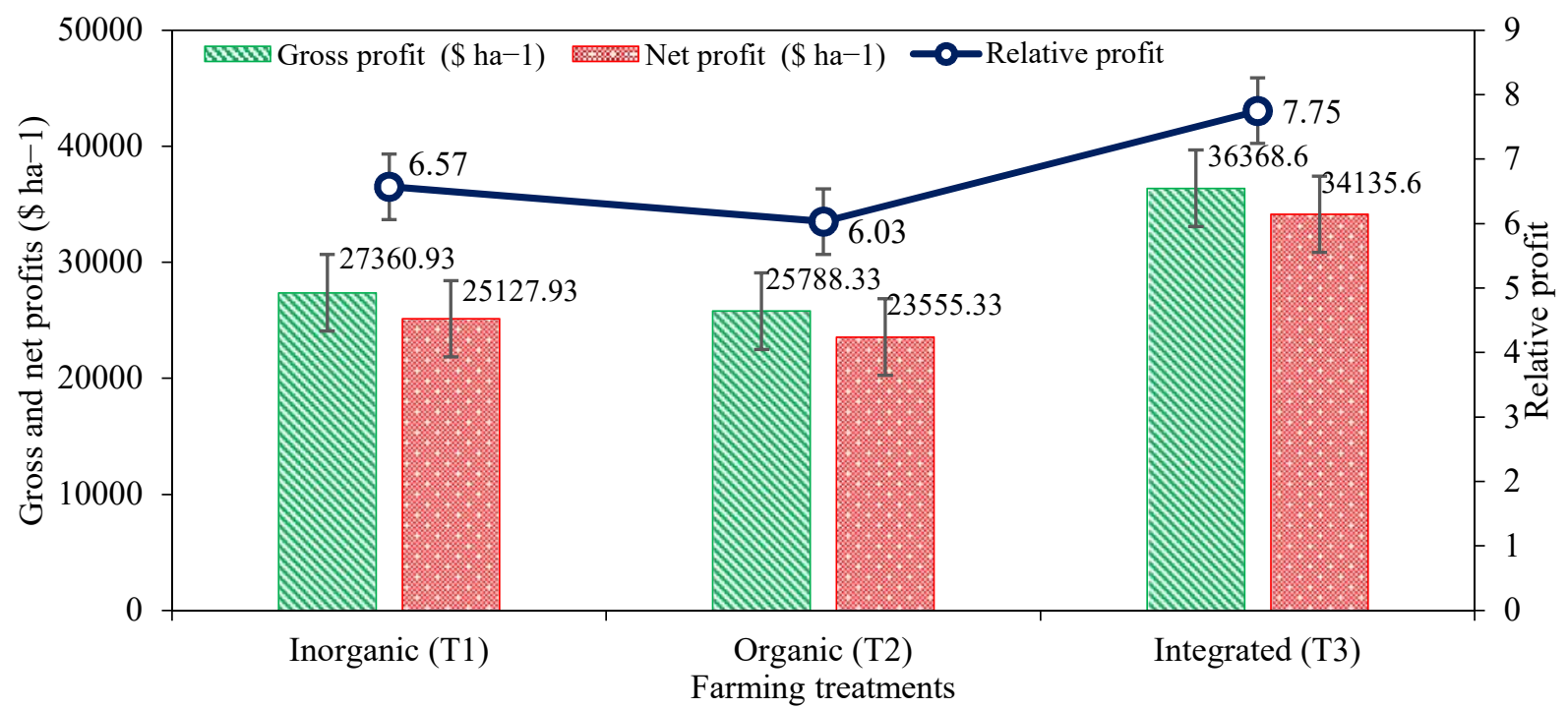

Figure 2. Calculation of profits of cucumber production under different farming treatments

The net profile was found by subtracting the production costs from gross output values and it was calculated as $25127.93,23555.33$ and $34135.60 \$ \mathrm{ha}^{-1}$ for the inorganic, organic and integrated fertilizer production of cucumber in greenhouse, respectively (Table 9). The results showed that the relative profit values for the greenhouse production was $6.57,6.03$ and 7.75 in three production systems, respectively. According to economic analysis results, the cucumber farming in greenhouses under three selected treatments proves to be a profitable 
agricultural activity and it is more profitable if using integrated fertilization. In the previous studies conducted to determine profitability of cucumber crops under greenhouse farming the relative profit was determined as 1.68 (Mirasi et al., 2015), 1.79 (Taki et al. 2012), 2.70 (Sami and Rehani, 2015).

Conclusion: The present study evaluated the yield, energy and economic analysis of greenhouse cucumber production under different farming treatments such as inorganic, organic and integrated fertilization application. The results indicated that the output energy is more than input energy utilization. Energy use efficiency were calculated as $4.19,4.84$ and 4.87 in inorganic, organic and integrated treatment systems, respectively. The energy analysis also explored the different energy ratios are good in all treatments. The energy budgeting (energy use efficiency $>1$; energy productivity $>1$; specific energy $<1$; and net energy $>0$ ) implies that the cucumber cultivation under greenhouse system is feasible but higher cucumber yield under integrated fertilizer treatment make the greenhouse cucumber production more feasible and adoptive. Among the different energy utilizing sources, the greenhouse structure, agricultural machinery, tractor and wood energies were calculated highest and accounts approximately $75 \%$ of the total energy utilization. The economic analysis in term of relative profits were calculated as $6.57,6.03$ and 7.75 under inorganic, organic and integrated greenhouse production. According to economic analysis results, the cucumber farming in greenhouse proved profitable agricultural activity and it is more profitable if using integrated fertilization treatment. The energy and economic analysis revealed that cucumber production in greenhouse under integrated fertilizer treatment seemed more profitable.

Author Contributions: Conceptualization, Design and Development, N.R.S. and Z.A.; Data collection, N.R.S. and Z.A.; Formal Analysis, N.R.S.; Investigation and Methodology, N.R.S. and Z.A.; Supervision, W.G.Y.; Visualization, N.R.S.; Writing - original draft, N.R.S. and Z.A.; Writing review, W.G.Y. and N.R.S.; Write-up editing, N.R.S. and Z.A.

Funding: This research received no external funding

Conflicts of Interest: The authors declared no conflict of interest.

Acknowledgments: The authors would like to acknowledge to all the services and technical support of PMAS-Arid Agriculture University Rawalpindi and Northeast Agricultural University, Harbin provided during research work setting, instrumentation, data collection and write-up compilation. Authors are also Thankful to the farmers Mr. Rana Noor Muhammad, Mr. Rana Shahid Noor and Dr. Rana Waseem Noor for their field knowledge and assistance in data collection during entire research work.

\section{REFERENCES}

Abdi, R., M. Taki, and M. Akbarpour (2012). An analysis of energy input-output and emissions of greenhouse gases from agricultural productions. Int. J. Nat. Eng. Sci, 6(3): 73-79.

Ali, Q., M.R. Yaseen and M.T.I. Khan (2019). Energy budgeting and greenhouse gas emission in cucumber under tunnel farming in Punjab, Pakistan. Sci. Hortic, 250: 168-173.

Aslam, W., and C. Hong (2018a). Comparative Profitability Analysis of Conventional and Organic Vegetable Farming in Khyber Pakhtunkhwa and Azad Jammu Kahsmir, Pakistan. J. Econ. Sustain. Dev, 9(8): 46-51.

Aslam, W., and C. Hong (2018b). Recent Trends in Adoption of Organic Farming in Pakistan: A Case Study. J. Econ. Sustain. Dev, 9(8): 147155.

Aslam, W., C. Hong, A.M. Maroof, R.M. Rana, A. Saima, and A. Ali (2017). Comparison of Organic Farming and Conventional Farming in the Punjab, Pakistan. Int. J. Sci. Eng. Res, 8(4): 29-38.

Aslam, W., R.S. Noor, F. Hussain, M. Ameen, S. Ullah, and C. Hong (2020). Evaluating Morphological Growth, Yield, and Postharvest Fruit Quality of Cucumber (Cucumis Sativus L.) Grafted on Cucurbitaceous Rootstocks. Agriculture, 10: 101-120.

Aydin, B., D. Aktürk, E. Özkan, H. Hurma, and M.A. Kiraci (2019). Comparative energy use efficiency and economic analysis of apple production in Turkey: case of Thrace Region. Erwerbs-Obstbau, 61(1): 39-45.

Baran, M.F., F. Lüle, and O. Gökdoğan (2017). Energy input-output analysis of organic grape production: a case study from Adiyaman Province. Erwerbs-Obstbau, 59(4): 275-279.

Benli, H. (2019). Techno-economic analysis of solar greenhouses. Int. J. Veg. Sci. 26(3): 249-261.

Bolandnazar, E., A. Rohani, and M. Taki (2019). Energy consumption forecasting in agriculture by artificial intelligence and mathematical models. Energ. Source. Part A: Reco. Utili. Env. Effect, 42(13): 1618-1632.

Canakci, M., and I. Akinci (2006). Energy use pattern analyses of greenhouse vegetable production. Energy, 31(8-9): 1243-1256.

Çebi, Ü.K., B. Aydin, R. Çakır, and S. Altıntaş (2019). Energy use efficiency and economic analysis of greenhouse cucumber farming in Turkey: case 
of Thrace Region. Cust. Agronegocio, 15(2): 221.

Dalgaard, T., N. Halberg, and J.R. Porter (2001). A model for fossil energy use in Danish agriculture used to compare organic and conventional farming. Agric. Ecosyst. Environ. 87(1): 51-65.

De Jager, A., D. Onduru, M. Van Wijk, J. Vlaming, and G. Gachini, (2001). Assessing sustainability of low-external-input farm management systems with the nutrient monitoring approach: a case study in Kenya. Agric. Syst, 69(1-2): 99-118.

Ekinci, K., V. Demircan, A. Atasay, D. Karamursel, and D. Sarica (2020). Energy, Economic and Environmental Analysis of Organic and Conventional Apple Production in Turkey. Erwerbs-Obstbau, 62: 1-12.

Elisabeth, D.A.A., S. Mutmaidah, and A. Harsono (2019). Adoption Determinants of Biofertilizer Technology for Soybean in Rainfed Area. IOP Conf. Ser.: Earth Environ. Sci, 347(1): 012114.

Härtl, F.H., C. Paul, T. Knoke (2019). Cropping systems are homogenized by off-farm income-Empirical evidence from small-scale farming systems in dry forests of southern Ecuador. Land use policy, 82: 204-219.

Houshyar, E., T. Dalgaard, M.H. Tarazkar, and U. Jørgensen (2015). Energy input for tomato production what economy says, and what is good for the environment. J. Clean. Prod, 89: 99-109.

Ilahi, S., Y. Wu, M.A.A. Raza, W. Wei, M. Imran, and L. Bayasgalankhuu (2019). Optimization Approach for Improving Energy Efficiency and Evaluation of Greenhouse Gas Emission of Wheat Crop using Data Envelopment Analysis. Sustainability, 11(12): 3409.

Khan, M.T.I., Q. Ali, and M. Ashfaq (2018). The nexus between greenhouse gas emission, electricity production, renewable energy and agriculture in Pakistan. Renew. Energy, 118: 437-451.

Kilcher, L. (2006). How can organic agriculture contribute to sustainable development? In: Tropentag 2006 "Prosperity and Poverty in a Globalised World-Challenges for Agricultural Research". University of Bonn, Germany, p. 57.

Kuswardhani, N., P. Soni, G.P. Shivakoti (2013). Comparative energy input-output and financial analyses of greenhouse and open field vegetables production in West Java, Indonesia. Energy, 53: 83-92.

Li, W., X. Wei, R. Zhu, K. Guo, (2019). Study on Factors Affecting the Agricultural Mechanization Level in China Based on Structural Equation Modeling. Sustainability, 11(1): 51.

Mengistu, T.W., S. Gupta, and R. Birner (2018). Analysis of maize biomass use in Ethiopia and its implications for food security and the bioeconomy. Food Secur, 10(6): 1631-1648.

Mirasi, A., M. Samadi, A.H. Rabiee (2015). An analytical method to survey the energy input-output and emissions of greenhouse gases from wheat and tomato farms in Iran. Biol. Forum Int. J, 7: 5258.

Mohamed, M.A., A.N.O. Kheiry, A.E. Rahama, A.A. Alameen (2017). Optimization Model for Machinery Selection of Multi-Crop Farms in Elsuki Agricultural Scheme. Turkish J. Agri. Food Sci. Tech, 5(7): 739-744.

Mohammadi, A., A. Tabatabaeefar, S. Shahin, S. Rafiee, A. Keyhani (2008). Energy use and economic analysis of potato production in Iran a case study: Ardabil province. Energ. Convers. Manage. 49(12): 3566-3570.

Mohammadi, A., and M. Omid (2010). Economic analysis and relation between energy inputs and yield of greenhouse cucumber production in Iran. Appl. Energy, 87(1): 191-196.

Nabavi-Pelesaraei, A., S. Rafiee, H. HosseinzadehBandbafha, S. Shamshirband (2016). Modeling energy consumption and greenhouse gas emissions for kiwifruit production using artificial neural networks. J. Clean. Prod. 133: 924-931.

Naresh, R., P. Jat, V. Kumar, S. Singh, Y. Kumar (2018). Carbon and nitrogen dynamics, carbon sequestration and energy saving in soils under different tillage, stubble mulching and fertilizer management in rice-wheat cropping system. J. Pharmacogn. Phytochem. 7(6): 723-740.

Noor, R.S., Hussain, F. and Umair, M. (2020a). Evaluating Selected Soil Physical Properties Under Different Soil Tillage Systems in Arid Southeast Rawalpindi, Pakistan. J. Clean WAS, 4(2): 41-45.

Noor, R.S., Hussain, F., Farooq, M.U. and Umair, M. (2020b). Cost and Profitability Analysis of Cherry Production: The Case Study of District Quetta, Pakistan. Big Data in Agriculture (BDA), 2(2): 65-71.

Noor, R.S., Z. Wang, M. Umair, M. Yaseen, M. Ameen, S.-U. Rehman, M.U. Khan, M. Imran, W. Ahmed, and Y. Sun (2019b). Interactive Effects of Grafting Techniques and Scion-Rootstocks Combinations on Vegetative Growth, Yield and Quality of Cucumber (Cucumis sativus L.). Agronomy, 9(6): 288.

Noor, R.S.; Wang, Z.; Umair, M.; Ameen, M.; Imran, M.; Sun, Y. (2019a). Performance Evaluation of a Water Seed Drill. Sustainability, 11(1): 137.

Omid, M., F. Ghojabeige, M. Delshad, H. Ahmadi (2011). Energy use pattern and benchmarking of selected greenhouses in Iran using data 
envelopment analysis. Energ. Convers. Manage, 52(1): 153-162.

Ozkan, B., R.F. Ceylan, H. Kizilay (2011). Comparison of energy inputs in glasshouse double crop (fall and summer crops) tomato production. Renew. Energy, 36: 1639-1644.

Pellegrini, P., and R.J. Fernández (2018). Crop intensification, land use, and on-farm energy-use efficiency during the worldwide spread of the green revolution. Proc. Natl. Acad. Sci, 115(10): 2335-2340.

Prajapat, K., A. Vyas, S. Dhar, N. Jain, M. Hashim, and G. Choudhary (2018). Energy input-output relationship of soybean-based cropping systems under different nutrient supply options. J. Environ. Biol, 39(1): 93-101.

Rigby, D., and D. Cáceres (2001). Organic farming and the sustainability of agricultural systems. Agric. Syst, 68(1): 21-40.

Saad, A., T. Das, D. Rana, A. Sharma, R. Bhattacharyya, and K. Lal (2016). Energy auditing of a maizewheat-greengram cropping system under conventional and conservation agriculture in irrigated north-western Indo-Gangetic Plains. Energy, 116: 293-305.

Sami, M., and H. Reyhani (2015). Environmental assessment of cucumber farming using energy and greenhouse gas emission indexes. IIOAB J. 6(5): 15-21.

Singh, H., D. Mishra, N. Nahar, and M. Ranjan (2003). Energy use pattern in production agriculture of a typical village in arid zone India: part II. Energ. Convers. Manage, 44(7): 1053-1067.

Taki, M., Y. Ajabshirchi, H.G. Mobtaker, and R. Abdi (2012). Energy consumption, input-output relationship and cost analysis for greenhouse productions in Esfahan Province of Iran. J. Exp. Agric. Int, 2(3): 485-501.

Tavares, V., N. Lacerda, and F. Freire (2019). Embodied energy and greenhouse gas emissions analysis of a prefabricated modular house: The "Moby" case study. J. Clean. Prod, 212: 1044-1053.

Teh, S.H., T. Wiedmann, R.H. Crawford, and K. Xing (2019). Assessing Embodied Greenhouse Gas Emissions. In: Decarbonising the Built Environment (Eds: Newton, P., Prasad, D., Sproul, A., \& White, S.), Palgrave Macmillan, Singapore, p. 119-141.

Yelmen, B., H. Şahin, and M. Çakir (2019). Energy Efficiency and Economic Analysis in Tomato Production: A Case Study of Mersin Province in the Mediterranean Region. Appl. Ecol. Env. Res, 17(4): 7371-7379.

Yildizhan, H., and M. Taki (2018). Assessment of tomato production process by cumulative energy consumption approach in greenhouse and open field conditions: Case study of Turkey. Energy, 156: 401- 408 .

Yilmaz, I., H. Akcaoz, B. Ozkan (2005). An analysis of energy use and input costs for cotton production in Turkey. Renew. Energy, 30(2): 145-155.

Yousefi, M., F. Darijani, and A.A. Jahangiri (2012). Comparing energy flow of greenhouse and open-field cucumber production systems in Iran. Afr. J. Agric. Res, 7(4): 624-628.

Yuan, S., and S. Peng (2017). Trends in the economic return on energy use and energy use efficiency in China's crop production. Renew. Sust. Energ. Rev, 70: 836-844. 